DOI:10.30842/ielcp230690152337

\author{
M. N. Kazanskaya \\ (Institute for Linguistic Studies, RAS, St. Petersburg)
}

\title{
THE TESTING OF THE BOW IN ANACREONTEA 33
}

The paper analyzes poem 33 of the Anacreontea (collection of poems in the Anacreontic style dating from the Imperial times); the poem describes the poet's encounter with Eros on a rainy night and the cruelty of the god who shoots the poet through the heart only to test whether his bow had suffered any damage in the rain. At first glance, the poem gives the impression of a simple, fable-like narrative; however, a closer look unveils a series of allusions and references to literary models (especially, to Homer). Most commentators consider the killing of the suitors in Odyssey $21\left(\mu \nu \eta \sigma \tau \eta \rho о \varphi v^{\prime} \alpha\right)$ as the Anacreontic poet's main model. The article shows that this Homeric allusion is in fact elegantly combined with a reference to Herodotus, and that Eros' last words evoke Hdt. 3, 35.

Key words: Anacreontea, Greek poetry of the Imperial period, Homeric reception, Hellenistic poetry, Homer, Theocritus, Herodotus.

М. Н. Казанская

(Институт лингвистических исследований РАН, Санкт-Петербург)

\section{Испытание лука в Anacreontea 33}

Статья посвящена стихотворению 33 из сборника Anacreontea (подражаний Анакреонту, восходящих к эпохе империи), описывающему встречу ненастной ночью поэта с Эротом и жестокость бога, который вместо благодарности стреляет поэту в сердце, проверяя, что его лук не пострадал от сырости. Это стихотворение, которое при первом прочтении оставляет впечатление простого, близкого басне рассказа, при ближайшем рассмотрении обнаруживает ряд аллюзий и отсылок к литературным моделям (особенно к Гомеру). Большинство комментаторов считают основной моделью Anacreontea 33 сцену убийства женихов в 21 песни Одиссеи ( $\mu \nu \eta \sigma \tau \eta \rho о р о v i ́ \alpha)$. В статье показывается, что на деле гомеровская аллюзия изысканно сочетается с отсылкой к Геродоту, а последние слова Эрота отсылают к Hdt. 3, 35.

Ключевые слова: Anacreontea, греческая поэзия эпохи империи, гомеровская рецепция, эллинистическая поэзия, Гомер, Феокрит, Геродот.

Among the collection of poems in Anacreontic style transmitted in the codex Palatinus gr. 23 and known as the Anacreontea, one describes the poet's encounter with Eros on a rainy night. This charming poem is one of the better-known pieces of the collection, 
and has enjoyed a fairly rich poetic afterlife ${ }^{1}$. We start by quoting the text as given by M. L. West:

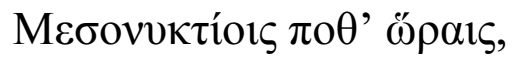
1 Once in the midnight hours

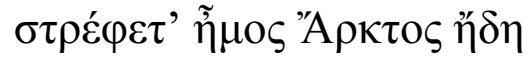

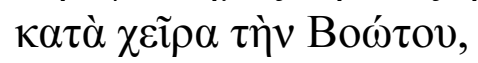

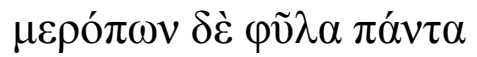
as the Bear is already turning
by Bootes' arm,
and all the tribes of mortals

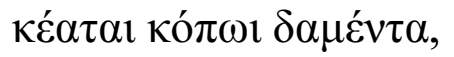

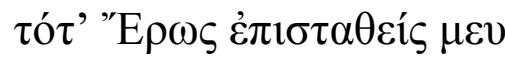

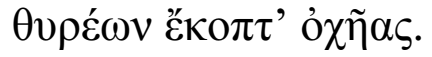

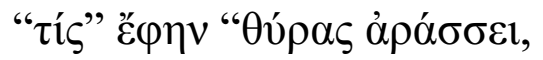

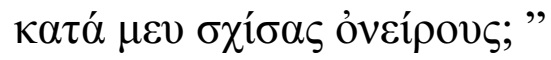

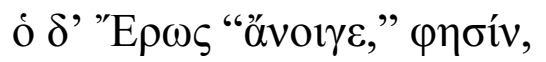

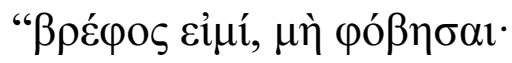

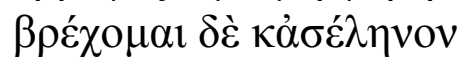

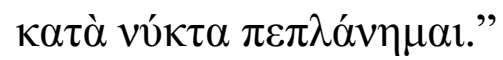

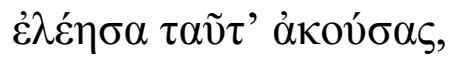

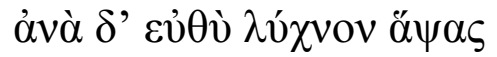

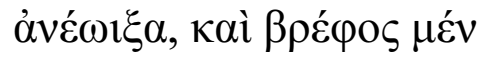

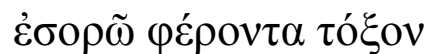

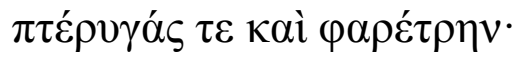

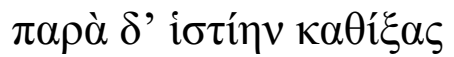 $\pi \alpha \lambda \dot{\alpha} \mu \alpha 1 \varsigma \tau \varepsilon \chi \varepsilon \tilde{\varepsilon} \rho \alpha \varsigma \alpha \tau^{2} \tau 0 \tilde{v}$

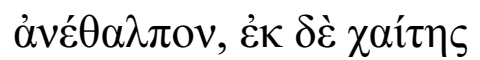

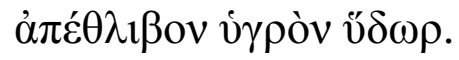

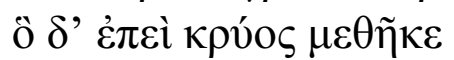

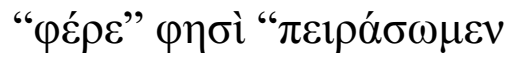

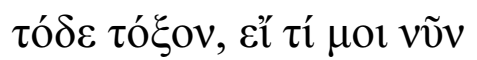

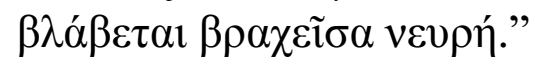
5 lie overpowered by weariness, it was then that Eros showed up and started beating the bolts of my door, "Who," said I, "pounds at my door, having ripped my dreams apart?"
10 And Eros answered: "Open! I am but an infant - have no fear! I am wet to the bone and lost (wandering) in the moonless night."
Upon hearing this, I took pity,
15 and lighting right away my lamp
I opened <the door $>$, and lo, I see an infant, carrying a bow, and wings, and a quiver; and, having seated him by the hearth,
20 with my palms I warmed his hands, and from his hair I dried wet water. And, once recovered from the cold, he says: "Say, let us test
25 this bow, whether the string has been harmed by the moist".

\footnotetext{
${ }^{1}$ First-rate European poets engaged in translating and imitating the Anacreontea 33: see, among others, Robert Herrick "One silent night of late..." (Hesperides, 1648); Lord Byron "'Twas now the hour when Night had driven..." (Hours of Idleness, 1805-1807), Rémy Belleau "N'agueres en plein mi-nuit..." (Les Odes d'Anacréon Téien, I, 15; 1556), Pierre de Ronsard "Il estoit minuiet, et l'ourse..." (Odes II, 164; 1550), Jean de La Fontaine "J'étois couché mollement..." (Contes, 1665), A. D. Kantemir "Нъкогда, въ часы полночны... " (1744), M. V. Lomonosov "Ночною темнотою..." (1747), Sumarokov "Во мразныя минуты...", and others. Henryk Sienkiewicz in his novel Quo vadis has Petronius recite to him the Anacreontic poem about Eros stranded on a rainy night before committing suicide under Nero's orders. A fuller list of translations and imitations of this poem can be gathered in works on anacreontic poetry in the XVI-XIX centuries (see Delboulle 1891; Gillespie 2002; Sviyasov 1998: 38; Gukovky 1927; Lappo-Danilevsky 2017).
} 


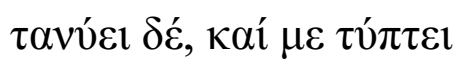

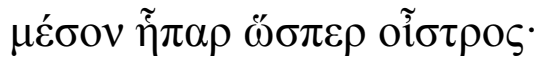

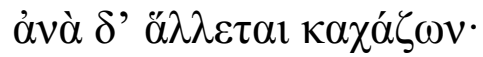

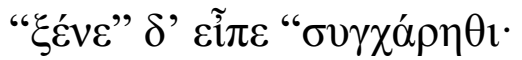

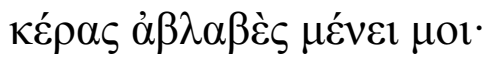

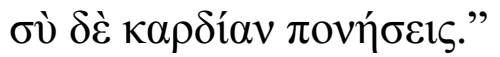

He stretches it, and hits me in the middle of my liver, like a sting, and leaps up, laughing gleefully:

30 "Host," he said, "share my joy!

My bow is unharmed,

while you will suffer in your heart".

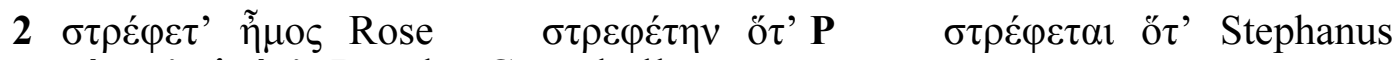

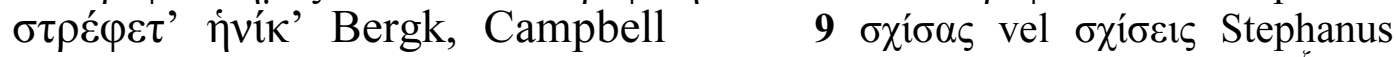
$\sigma \chi i \zeta \varepsilon \imath \sigma \mathbf{P} \quad \sigma \kappa \varepsilon \delta \tilde{\alpha} \varsigma$ Richards $11 \varphi \circ \beta \tilde{\eta} \sigma(\alpha) \mathbf{P} \quad \varphi \circ \beta \eta \theta \tilde{\eta} \varsigma$ Blaydes $19 \kappa \alpha \theta i \sigma^{\xi} \alpha \sigma \mathbf{P}$

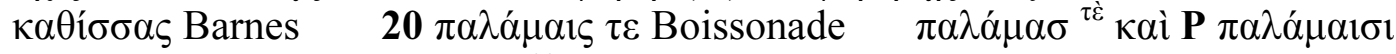

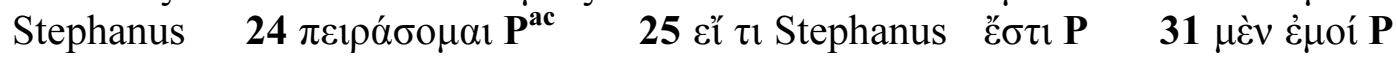

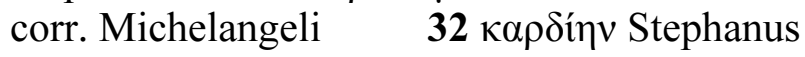

The poems of the Anacreontea are difficult to date; the earliest were probably written in the first century BC, while others could be as late as the sixth century $\mathrm{AD}^{2}$. Poem 33 may be one of the earlier ones, elegantly combining motifs typical of Hellenistic poetry with expressions reminiscent of epics and of Homeric style (both will be studied below). This combination of Alexandrian and Homeric poetics has led a number of scholars to suggest that Eros' breach of xenia and his unexpected cruelty towards his host also carried Homeric associations and was meant to evoke the testing of the bow in Odyssey 21 and Odysseus' killing the suitors ${ }^{3}$. However, a closer examination of the two texts shows little resemblance in wording ${ }^{4}$,

${ }^{2}$ Hopkinson (1994: 71) gives a slightly larger range: "None of the poems can be precisely dated, but studies of their language and metre have shown that they vary in date between perhaps the second century $\mathrm{BC}$ and the end of pagan antiquity".

${ }^{3}$ Thus, West (1984: 25) in his apparatus criticus refers to Od. 21, 393sqq; the suggestion is accepted by Hopkinson (1994: 74-75) and Rosenmeyer (1992: 104).

${ }^{4}$ Following West's suggestions in his apparatus criticus (West 1984: 25),

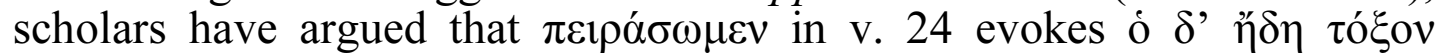

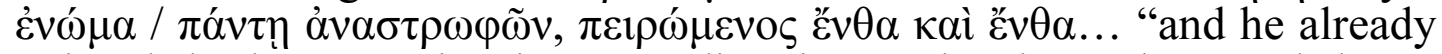
pointed the bow, turning in every direction, trying it out here and there"

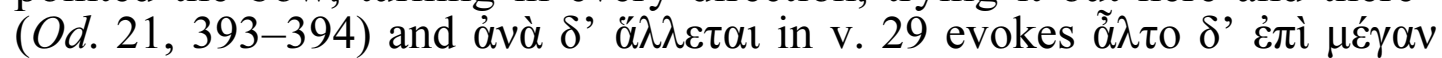

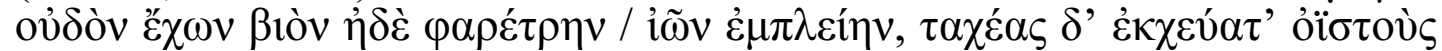

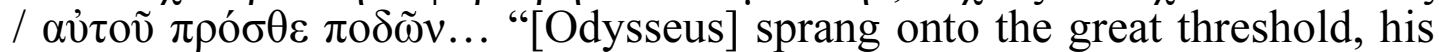
bow and quiver in his hand, and poured his swift shafts out [on the floor] before his feet" (Od. 22, 2-4; see Hopkinson 1994: 75 ad v. 24-32 [41-9]; Rosenmeyer 1992: 104; Sens 2014: 101). However, these similarly sounding expressions denote very different actions: $\pi \varepsilon i \rho \alpha ́ \sigma \omega \mu \varepsilon v(\mathrm{v} . ~ 24)$ refers to Eros' actually shooting the shaft, while Odysseus had only been flexing his bow and aiming it in different directions (moreover, as noted by Hopkinson, 1994: 75 ad v. 24 [41], $\pi \varepsilon i \rho \alpha ́ \sigma \omega \mu \varepsilon v$ and $\pi \varepsilon \imath \rho \omega ́ \mu \varepsilon v o \varsigma$ are forms 
and the resemblance between the situations described in the Anacreontic poem and in the Odyssey proves rather superficial ${ }^{5}$. No one but the poet is injured by Eros' arrow, neither is he killed by it. There is no contest in archery in Anacreontea 33 as one sees in Odyssey 21. Most importantly, the culmination of the story in Eros' cruel joy and his call on the host to join him in his happiness finds no parallel in Homer, although one would expect to find something similar in the $\mu v \eta \sigma \tau \eta \rho o p o v i ́ \alpha$, if Homer were indeed the Anacreontic poet's only source. I would like to suggest that the ending of the poem evoked a different type of literary model - a text that provides a close and meaningful parallel both to the development of the story and to Eros' last words.

However, before addressing the problem of literary sources for the testing of the bow in Anacreontea 33, it seems worthwhile to analyze Homeric elements in this poem and the use that the poet puts them to. Throughout the poem Homer's influence is manifest (a) in the usage of epic forms, and (b) in the choice expressions that are closely modelled on Homeric formulas. These elements stand out against the Hellenistic basis of the poem. Anacreontea 33 for the most part is written in the poetic koine, with the exception of a number of incorporated Homeric expressions (they will be listed below). The representation of Eros as a child (here designated as $\beta \rho \varepsilon ́(\rho)$ ) is obviously a commonplace for Hellenistic and later Roman literature and art; Eros' plight is likewise a frequent Hellenistic motif, as is, of course, Eros' cruelty. Hellenistic background is also noticeable in the indication of the hour of the

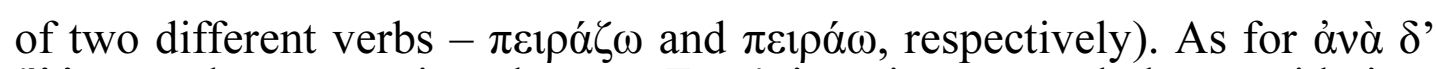
$\ddot{\alpha} \lambda \lambda \varepsilon \tau \alpha 1$, the expression denotes Eros' jumping up and down with joy, while $\tilde{\alpha} \lambda \tau$ o referred to Odysseus' springing up on the threshold of the chamber. In the latest commentary on the Anacreontea, Zotou (2014: 181 $a d$ v. 24-31) rightly stresses that neither of the verbs is specific enough to serve as basis for an allusion, unless supported by other correspondences.

${ }^{5}$ Doubts as to whether the killing of the suitors is a proper intertext for the end of the Anacreontea 33 have recently been expressed by Zotou (2014: 181 ad v. 24-31): "Zwar enthält unser Text epische Züge, aber in diesem bestimmten Punkt sind keine wesentlichen Ähnlichkeiten mit der gerade

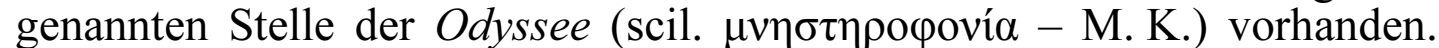
[...] Die Formulierungen der beiden Texte sind zwar ähnlich, weil sie sich auf das gleiche Thema beziehen, haben aber darüber hinaus keinen weiteren inhaltlichen Zusammenhang. Wie könnte sich hier der anakreontische Dichter auch anders äußern, um das Ausprobieren und Dehnen des Bogens zu beschreiben?" However, Zotou's own attempt at creating a sense of unity between the bulk of the poem and its ending (v. 30-32) results in a patent overinterpretation of the text (ibid., 182). 


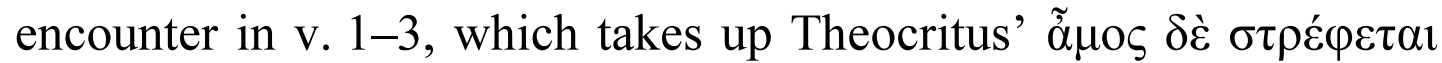

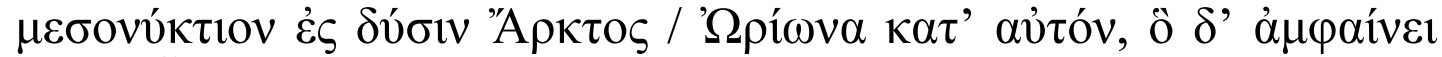

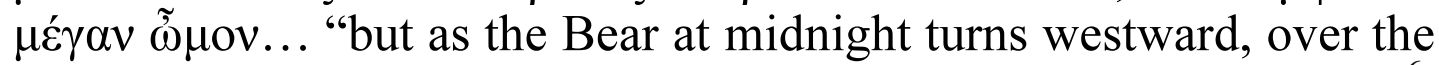
Orion himself, who shows his great shoulder,..." (Id. 24, 11-12) ${ }^{6}$. Indeed, the similarity of the two passages is so striking that $\tilde{\alpha} \mu \mathrm{o} s . .$. $\sigma \tau \rho \varepsilon \dot{\varphi} \varepsilon \tau \alpha \iota$ in Theocritus suggested the correction of the ms. reading

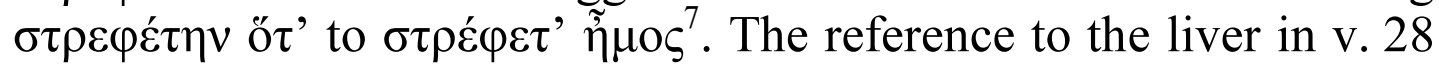
as the seat of erotic passion is also proper to Hellenistic and Roman poetry ${ }^{8}$. Finally, M. L. West suggested in the apparatus criticus to

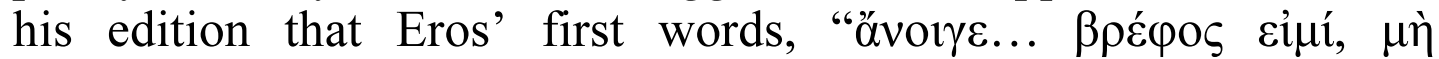

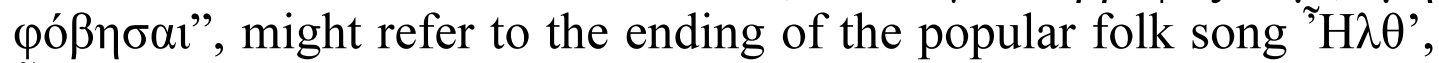
$\tilde{\eta} \lambda \theta \varepsilon \chi \varepsilon \lambda 1 \delta \omega ́ v .$. ("There came, there came the swallow..."):

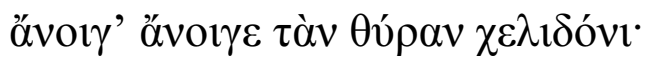

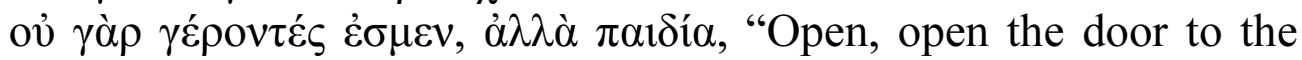
swallow: for we are not old men, but children" (Carm. pop. PMG 848, 18-19).

The incorporation of popular poetry and other genres of folklore is a favourite practice with Hellenistic poets ${ }^{9}$. Here, however, the

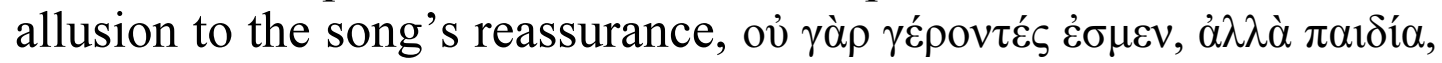

${ }^{6}$ See Hopkinson (1994: 74, ad 1-3 [18-20]); Zotou (2014: 179); Theocritus' passage, those primary function is to denote the time of the year when the babies Heracles and Iphicles were attacked by snakes as mid-February (see Gow 1952: 417-418 ad Id. 24, 11f.; Dover 1971: 254 ad Id. 24, 11f.), also carries Homeric associations (see below).

${ }^{7}$ This correction is accepted by the majority of editors: see West (1984: 24), Hopkinson (1994: 15), Zotou (2014: 178); Campbell (1988: 202), on

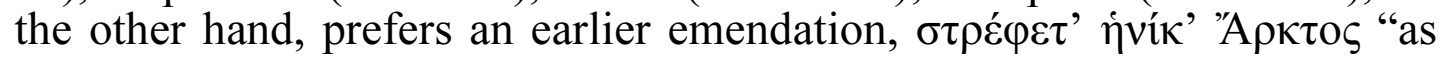
Arctos is turning", that had been proposed by Bergk (1882: 315, no. 31 [3]) In defense of the manuscript reading, see Giangrande (1975: 193-195),

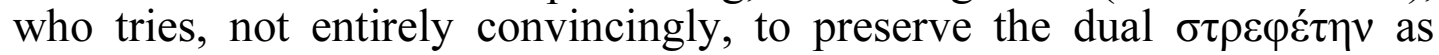
referring to the Ursa maior and the Ursa minor.

${ }^{8}$ The liver begins to appear as the seat of desire from Hellenistic poetry on, whereas in earlier authors it was usually mentioned as the seat of violent passions, such as anger and rage (cf. $L S J$ 1996: 776, s.v. $\tilde{\eta} \pi \alpha \rho)$. The earliest occurrence of $\tilde{\eta} \pi \alpha \rho$ in the erotic context is Theocritus (Id. 11, 15-16 and 13, 71; cf. Moschus 2, 16-17); the idea was later taken over by Roman poets (cf. Horace, Carm. 1, 25, 15; 4, 1, 12; Ep. 1, 18, 72; etc.). See also Rosenmeyer (1999: 37 n. 50).

${ }^{9}$ E.g., Callimachus (on the use of folklore in his Iambi, see Lelli 2003; Scodel 2011) or Theocritus (on the presence of folk genres in the Idyllia, see Dover 1971: XLIX-L; Fantuzzi, Hunter 2005: 33-34). As for Anacreotea 33, West's suggestion is welcomed by Zotou (2014: 180, ad 10f.) who cites it in support of her idea that popular songs might have influenced the Anacreontic poet's penchant for alliterations. 
might suggest to the reader the famous distinction of the two Erotes - Eros as one of the oldest, primary gods known from Hesiod (Theog. 120-122) and Eros as child (the image that was particularly appreciated in Hellenistic and Roman times) ${ }^{10}$.

Against this Hellenistic background, the expressions associated with Homeric style and language (i.e. when the poet uses a form that stands out against the poetic koine) are easily recognized. Such is

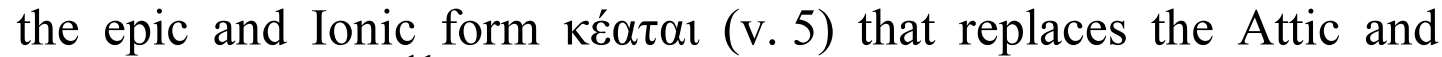
koine form $\kappa \varepsilon i v \tau \alpha l^{11}$, the form $\beta \lambda \alpha \dot{\beta} \varepsilon \tau \alpha 1$ in v. 26 (used instead of the

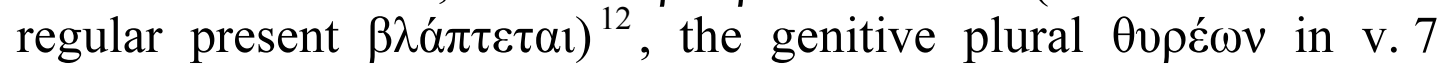
(instead of $\theta v \rho \tilde{\omega} v$ ). In v. 19 the participle $\kappa \alpha \theta i ́ \sigma \alpha \varsigma$ was corrected in the codex Palatinus to $\kappa \alpha \theta i \xi \alpha \varsigma$, reading retained by most editors since Henri Estienne as the lectio difficilior ${ }^{13}$ and one that Hopkinson is prepared to view as a nod to Homer ${ }^{14}$. The extensive

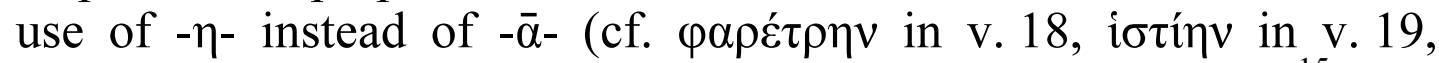

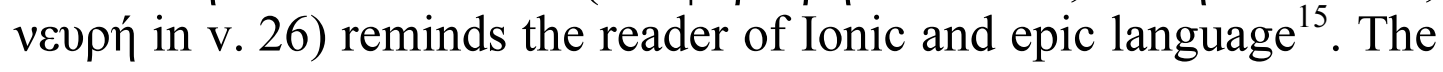

${ }^{10}$ The opposition of Eros the ever-young god and Eros as one of the oldest

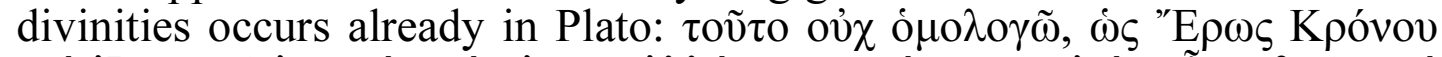

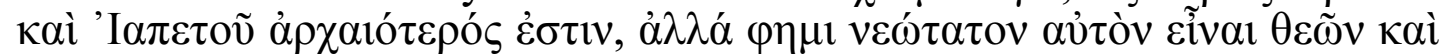
ácì véov... "I do not agree [with Phaedrus] in that Eros is older than Zeus and Iapetus, but I claim that he is the youngest of the gods and ever young..." (Plat. Symp. 195b). This opposition becomes a recurring motif in

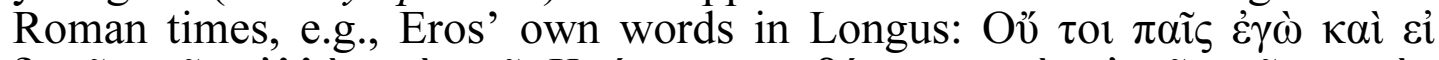

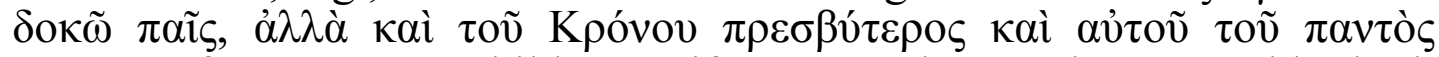
$\chi \rho$ óvov, "for I am not a child, even if I seem to be one, but I am older both than Cronos and than time itself..." (Daphn. 2, 5, 2; cf. Luc. Dial. deor. 6, 1 , etc.).

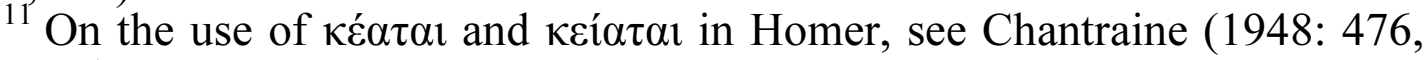
$\$ 228)$.

${ }^{12}$ The form $\beta \lambda \alpha \dot{\beta} \varepsilon \tau \alpha \mathrm{l}$ is noted as a Homerism by Hopkinson (1994, $75 \mathrm{ad}$ 26 [43]): " $\beta \lambda \alpha ́ \beta$ o $\mu \alpha 1$ is a rare Homeric variant form of $\beta \lambda \alpha ́ \pi \tau o \mu \alpha \imath$ "; cf. Chantraine (1948: 311): " $\beta \lambda \alpha ́ \beta \varepsilon \tau \alpha \iota[. .$.$] risque d'être une forme plus$

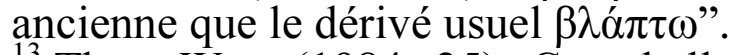

${ }^{13}$ Thus, West (1984: 25); Campbell (1988: 204); Hopkinson (1994: 16); Zotou (2014: 178); on the other hand, Bergk (1882: 316), following Mehlhorn, replaced the participle with the personal form $\kappa \alpha \theta \tilde{i} \sigma \alpha$.

${ }^{14}$ Hopkinson (1994: 75, ad 19 [36]): "Aorists in - $\xi$-from verbs in - $\zeta \omega$ are a feature of West Greek dialects; but, since such forms are occasionally found in Homer, $\kappa \alpha \theta i \xi \alpha \varsigma$ here may be intended as a poeticism rather than as a Dorism".

${ }^{15}$ The full list of Anacreontic poems that affect Ionic forms with - $\eta$ instead of $-\bar{\alpha}$ - are given by West (1984: XI); cf. Sens (2014: 101). Throughout the Anacreontea 33, $-\eta$ - is used so consistently instead of $-\bar{\alpha}-$ that Henri Estienne suggested reconstructing the Ionic form $\kappa \alpha \rho \delta i ́ \eta v$ for the

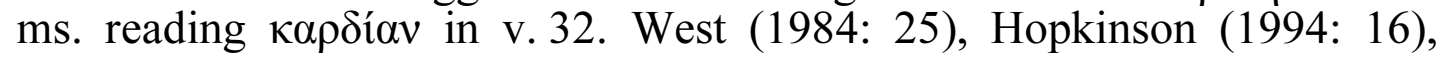


form $\mu \varepsilon v$ would also have carried associations with Homeric language for ancient readers, as - $\varepsilon v-$ was the standard rendering of the group - co- $^{-}$which did not undergo contraction in Ionic and in epic language ${ }^{16}$. Finally, Anacreontea 33 has the highest concentration of tmeses among the poems of the collection ( $\alpha \alpha \tau \alpha$

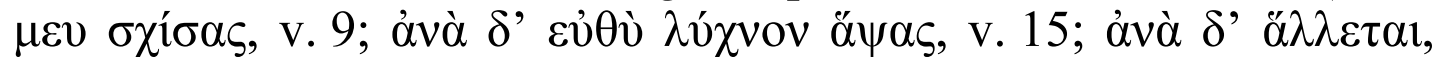
v. 29; the only other example of tmesis in the collection occurs at the beginning of the Anacreontea $60^{17}$. While Homer was obviously not the only poet to use tmesis, ancient grammarians associated it specifically with his style (and epic style in general) ${ }^{18}$, and three instances of tmesis in one poem clearly cannot be due to chance.

Expressions of the second kind - ones that are closely modelled on Homeric formulas and expressions - reinforce the epic overtones of the poem. And as some of them, moreover, evoke precise passages from Homer, they deserve to be examined one by one.

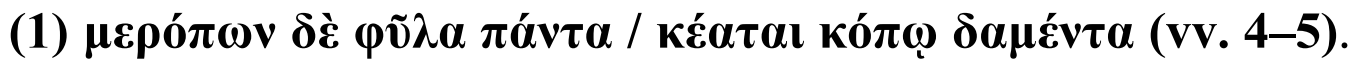
The very beginning of the poem contains a cluster of Homerisms. The expression $\mu \varepsilon \rho o ́ \pi \omega v \varphi \tilde{v} \lambda \alpha$ is clearly modelled on Homer's $\varphi \tilde{v} \lambda$ '

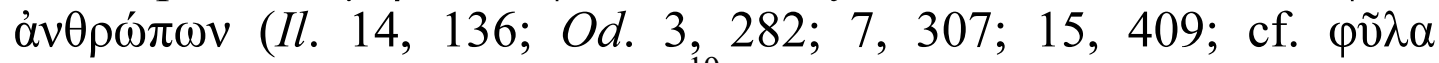

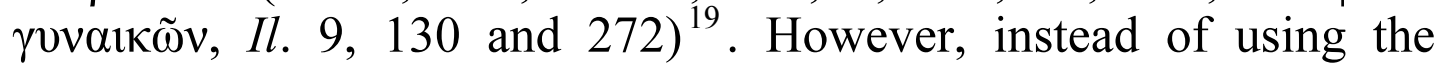
simpler word ớv $\theta \rho \omega \pi$ ol, the Anacreontic poet uses $\mu \varepsilon \varepsilon^{\rho} \rho \pi \varepsilon \varsigma$, which in its turn was taken over from another Homeric formula, usually

Zotou (2014: 178) do not follow this suggestion, preferring to preserve variation in forms.

${ }_{16}$ The group - $\varepsilon v-$ which is primarily a graphic convention is also sometimes called the Ionic contraction. On the phenomenon, see West (1974: 80); on the distribution of forms $\dot{\varepsilon} \mu \varepsilon \tilde{v}$ and $\mu \varepsilon v$ in dialects, see Schwyzer (1950: I, 604-605, 6.1.B.ß).

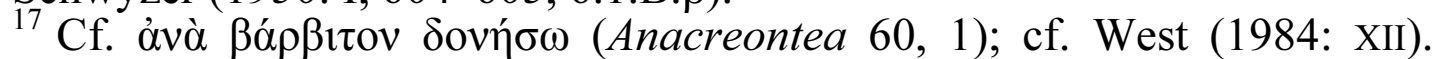
Tmesis is included by Hopkinson in his list of Homerisms in the Anacreontea 33 (see Hopkinson 1994: 73).

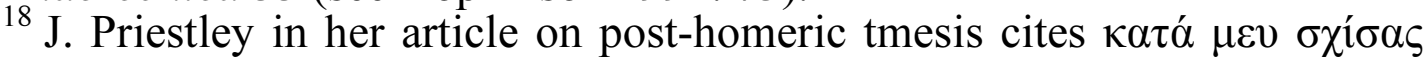
óveípous (v. 9) as an example of emotional tmesis in direct speech, regularly associated with hostility of tone (see Priestley 2009: 169); she does not take into account either the rarity of tmesis in the Anacreontea collection or the anomalous number of tmeses in poem 33.

${ }^{19}$ For a full list of occurrences of $\varphi \tilde{v} \lambda{ }^{\prime} \dot{\alpha} v \theta \rho \omega ́ \pi \omega v$ vel sim., see M. Schmidt, s.v. $\varphi \tilde{u} \lambda$ ov (LfgrE 1955-2006: IV, 1058-1061). The lemma defines the formula's use in the plural as practically identical with the pronoun 'all': "die Stämme, die Geschlechter der Menschen, meist als Umschreibung für 'alle', die ganze Gattung, bes. wenn Menschen Göttern gegenübergestellt werden..." (B 2 b in the lemma). 
used in Genitive plural, $\mu \varepsilon \rho o ́ \pi \omega v \dot{\alpha} v \theta \rho \omega ́ \pi \omega v^{20}$. The adjective $\mu \varepsilon \dot{\rho} о \pi \varepsilon \varsigma$ by Alexandrian times was understood to mean "mortals", but actually constituted a problem for Homeric scholars, as both its meaning and etymology were obscure ${ }^{21}$. Thus, in $\mu \varepsilon \rho o ́ \pi \omega v \varphi \tilde{\nu} \lambda \alpha$ the author of the Anacreontea 33 combines two expressions typical of Homer's style into one, thus showing himself more Homeric than Homer himself. The expression is closely followed by кó $\pi \omega$ $\delta \alpha \mu \varepsilon \dot{\varepsilon} \tau \alpha$, a participial construction evocative of numerous expressions for mortals (and sometimes, gods) "subdued" by sleep

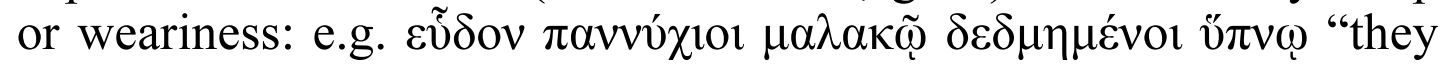
slept all night long, overpowered by soft sleep" (Il. 10, 2 = 24, 678;

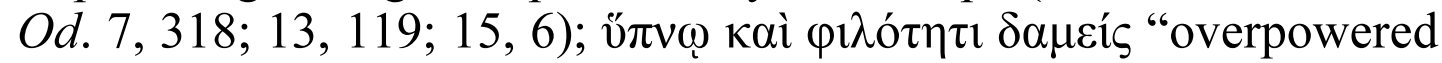
by sleep and love-making" (Il. 14, 353); etc. This insertion of a cluster of three expressions, all closely modelled on Homeric formulas, re-orientates the reader (if he had been able to recognize the Theocritean allusion in verses 1-3) to an epic intertext: this was all the more easy to do, seeing that Theocritus' $I d$. 24, 11-12 itself echoes the description of the night sky and the constellations depicted on Achilles' shield (Il. 18, 486-488; the verses are repeated at $O d .5,273-275)$.

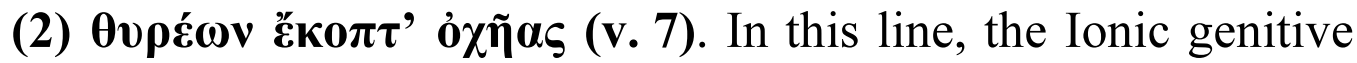
$\theta v \rho \varepsilon ́ \omega v$ already suggests an epic association, but in fact, the expression as a whole refers to a precise scene from the Odyssey, when Penelope goes to get Odysseus' bow from the vault. The poet details how the lock on the vault's door works:

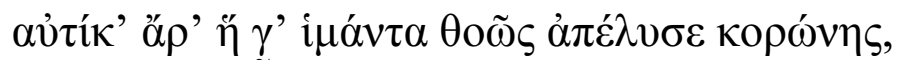

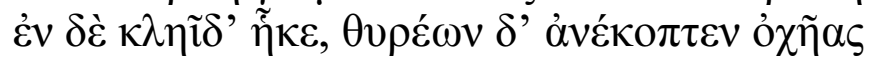

${ }^{20}$ Cf. Il. 1, 251; 3, 402; 9, 340; 11, 28; 18, 342; 19, 490; 20, 217; Od. 20,

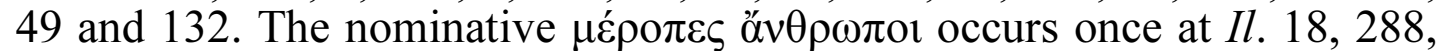
and there is one example of a dative plural, although the noun had to be

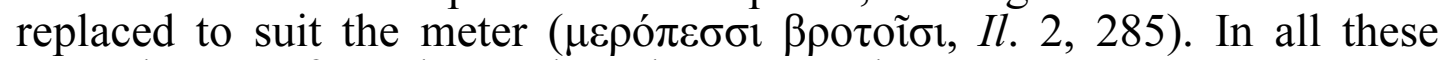
cases the noun formula stands at the verse end.

${ }_{21} \mathrm{Cf}$. the multiple explanations for $\mu \varepsilon \dot{\rho}$ o $\pi \varepsilon \varsigma$ cited in the scholia:

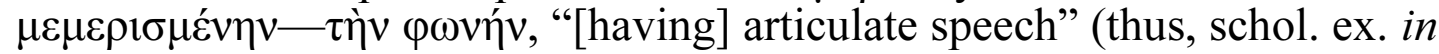

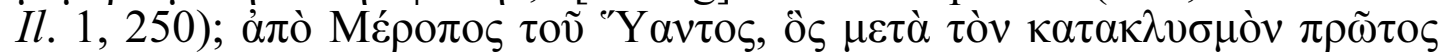

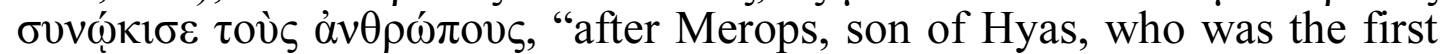
to found a settlement after the flood" (schol. A in Il. 1, 250) ì $\tau \tilde{\omega} v$

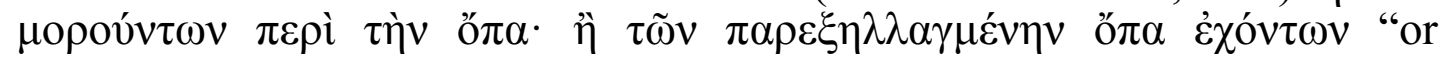
struggling with speech; or having a strange (literally, "modified') speech" (schol. A bT in Il. 1, 250). For modern scholarship, the origins of $\mu \varepsilon \dot{p} о \pi \varepsilon \varsigma$ remain unexplained: for a succinct summary of the question, see G. S. Kirk

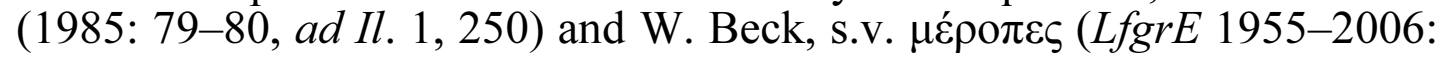
III, 153-154) with references. 


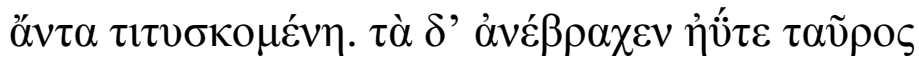

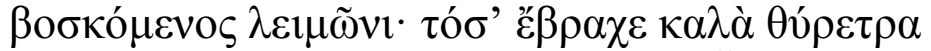

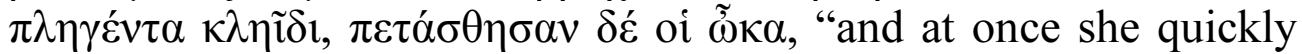
untied the <leather $>$ thong from the hook, and inserted the key, and shot back the bolts of the doors, taking a careful aim. And the bolts groaned, just like a bull who is grazing in the meadow; as loudly did the leaves of the door, hit by the key, groan, and they swiftly sprang $<$ open> before her" (Od. 21, 45-50).

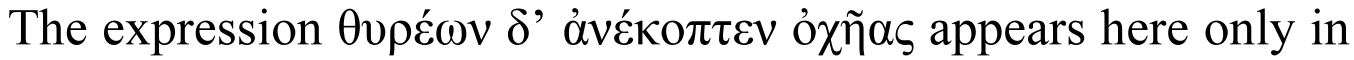
Homer and has visibly been created specifically for the description of how the sliding bolt lock works ${ }^{22}$ : the choice of the verb $\dot{\alpha} v \alpha \kappa o ́ \pi \tau \omega$ is well suited to the mechanism of the lock where the bulky bent key (probably shaped as the letter $\Sigma^{23}$ ) is used to strike the two bolts of the door out of their position. In the Anacreontea

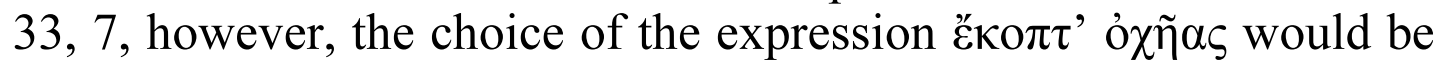
difficult to account for, unless one keeps the Homeric parallel in mind: seeing that the bolts of the host's door are on the inside, it would be difficult for Eros to strike them from outside ${ }^{24}$. However,

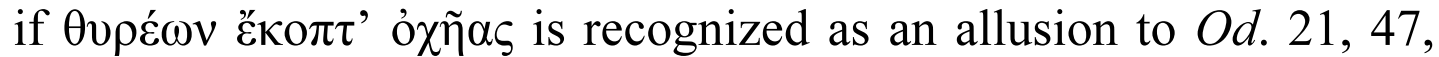
the unusual expression serves to draw attention to the intertext, giving the reader a first hint that a scene similar to the testing of the bow in the Odyssey might be about to take place.

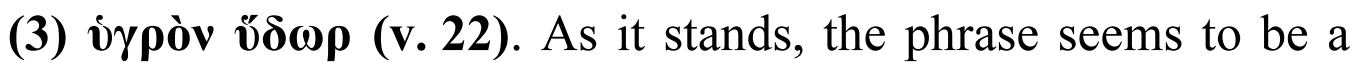
pleonasm, usually associated with popular unrefined style. However,

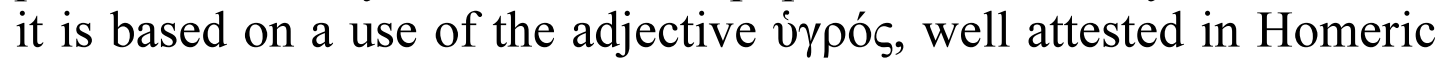
poems, to qualify different liquids, especially olive oil (cf. vंypòv

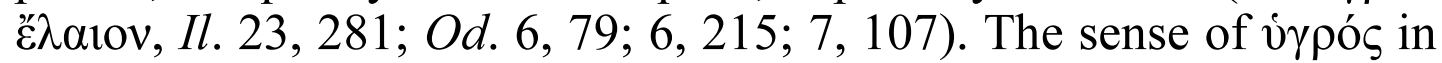
these passages is close to "flowing", and when applied to liquids can be qualified as an epithetum ornans, but not really as an instance of redundancy ${ }^{25}$. There is, however, one context where v̛ $\gamma \rho$ ó $\varsigma$ does give

${ }^{22}$ For details, see Fernández-Galliano's commentary on this scene in Russo, Fernández-Galliano, Heubeck (1992: 153).

${ }^{23}$ Thus, Fernández-Galliano on $O d$. 21, 6, with reference to T. Eide: "this key has to be inserted with some difficulty [...] into a gap or hole in order

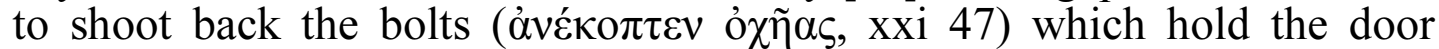
inside" (in Russo, Fernández-Galliano, Heubeck 1992: 149).

${ }^{24}$ The allusion to $O d$. 21, 46-48 is recognized by Sens (2014: 101). Hopkinson, who fails to notice the Homeric allusion, tries to explain (not quite convincingly) the expression $\theta v \rho \varepsilon \omega^{\prime} \omega v$ '̌ $\kappa о \pi \tau$ ' o $\chi \tilde{\eta} \alpha \varsigma$ as a result of the poet's terseness: "Briefly expressed, but the meaning is clear: he beat at the door, which was bolted on the inside" (see Hopkinson 1994: 75, ad 7 [24]). ${ }^{25}$ Cf. Chadwick (1996: 297): "Stock epithets may be obvious, but are surely never otiose"; he reconstructs the basic meaning of vypós as 
that impression - when Proteus assumes a series of different forms to avoid giving Menelaus the answers the latter wants:

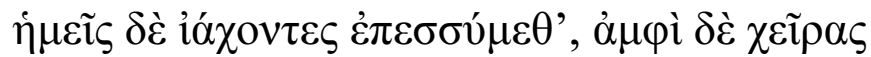

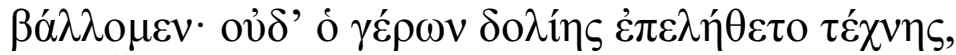

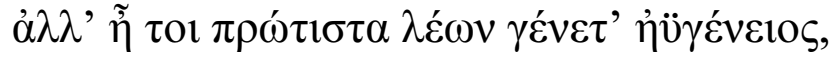

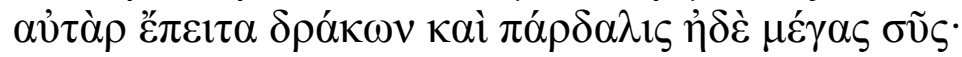

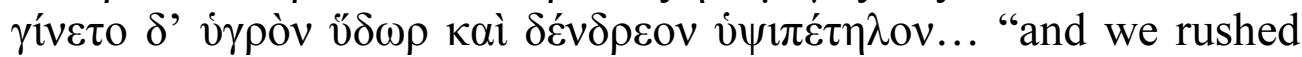
upon him with cries, and flung our arms around him: but the old man had not forgotten his cunning art, and first became a lion with a great beard, but then a serpent, then a panther, then a great wild boar, than he transformed himself into wet water and a tree with a sigh-soaring top" (Od. 4, 454-458).

Although the commentaries to Anacreontea 33, tend to mention Od. 4, 458 simply as a parallel, I would be prepared to see in the

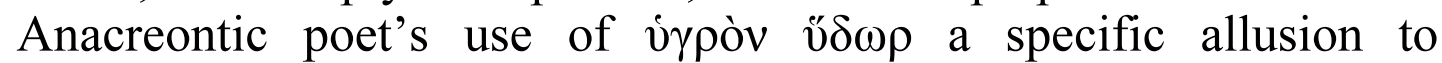
Menelaus' encounter with Proteus (see below).

(4) кร́pa for "bow" (v. 31). In his gleeful last remark Eros uses

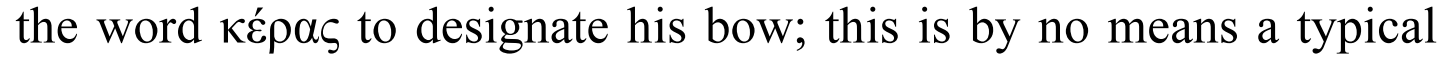
designation, and even in Homer this usage appears only once, when Odysseus checks to see whether his bow is intact after his many years of absence:

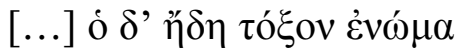

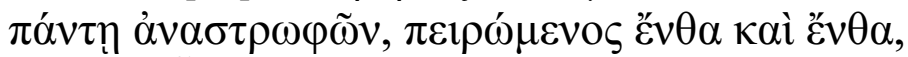

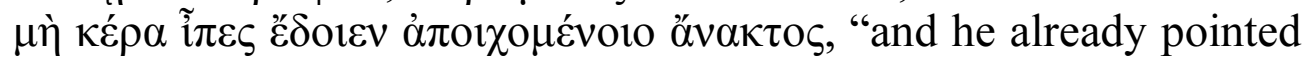
the bow, turning in every direction, trying it out here and there, to see whether the bow (literally, horn) suffered ${ }^{26}$ from wood-worms" (Od. 21, 393-395).

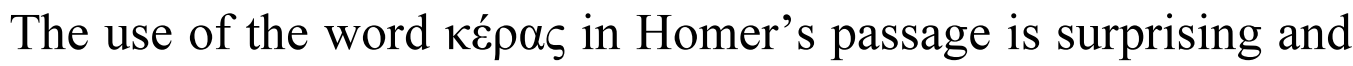
has no solid parallels: it has been interpreted in two ways, either as a metonymy (i.e. that Odysseus' bow is partly made of horn), or as a metaphor (i.e. that the curve of the bow is compared to the form of a horn) ${ }^{27}$. For the interpretation of Anacreontea 33, 31 the exact

running, flowing water (as opposed to stagnant water); see also the scholia

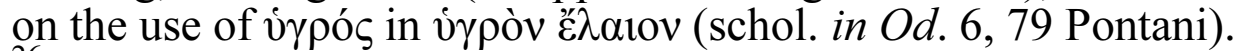

${ }^{26}$ The optative present $\varepsilon \delta o 1 \varepsilon v$ suggests that Odysseus is checking both (a) whether any damage had been done to the bow during his years of absence, and (b) whether the insects were not gnawing at the wood still (see Fernández-Galliano ad $O d$. 21, 395 in Russo, Fernández-Galliano, Heubeck 1992: 199).

${ }^{27}$ For Képas as designating a part of the bow, see M. Schmidt in $\operatorname{LfgrE}$ (1955-2006: II, 1384, s.v. Képas): 'Teil des Bogens'; Fernández-Galliano ad Od. 21, 395 in Russo, Fernández-Galliano, Heubeck 1992: 199). For the 


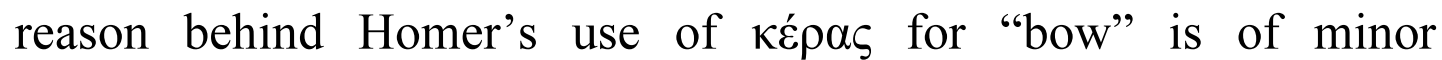
significance. Rather, it should be stressed that once more the Anacreontic poet makes use of a rare Homeric word in order to evoke a specific scene from the Odyssey (the testing of the bow), an episode, moreover, that would seem to have all the constituents to serve as a literary prototype for Eros' testing of his bow on his

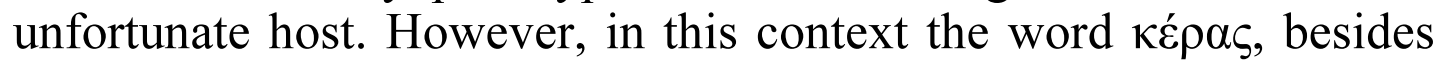
suggesting the Homeric allusion, seems to serve another purpose as well: because of its well attested, but vulgar metaphoric usage for male private $\operatorname{parts}^{28}$, the word adds a tongue-in-cheek pun to Eros'

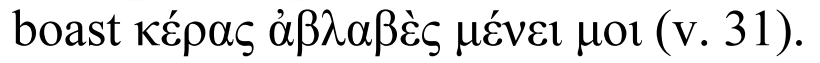

And yet, despite the fact that the poet repeatedly points toward the reader towards the Odyssey, both by using Homeric forms and expressions and by alluding to particular scenes, there is nothing in the $\mu \nu \eta \sigma \tau \eta \rho о \varphi$ oví $\alpha$ that can really parallel Eros' cruel call upon his

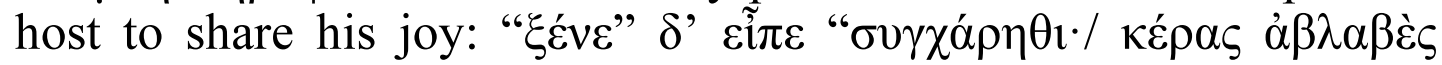

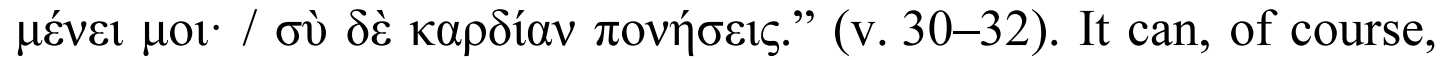
be argued that at this point the Anacreontic poet dismisses his literary model and invents an unexpected twist for his story; however, given the persistent use of literary references throughout the poem, one would expect Eros' pithy punchline to have a literary antecedent as well. And there is, in fact, one close parallel for the culmination of this scene that, as far as we were able to ascertain, has not been suggested before.

Herodotus at the beginning of book III of his Histories describes the Persian king Cambyses' gradual descent into madness. The first signs of the mental illness appear when Cambyses orders to mutilate and burn the mummy of the pharaoh Amasis (Hdt. 3, 16), and when he later undertakes an expedition against the Ethiopians without providing for his army, only turning back when the soldiers turn to eating each other $(3,25)$. As the illness progresses, Cambyses kills

idea that Képaৎ was a metaphoric designation, see Eckstein (1974: 41 n. 287). Obviously, whichever interpretation is prefered, one has to take

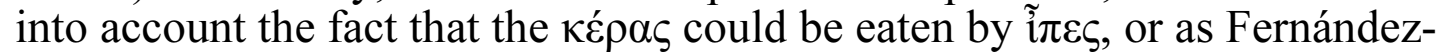
Galliano (ibid.) summarizes the problem: "It is not clear what sort of worm was meant, or whether there is a species which attacks horn".

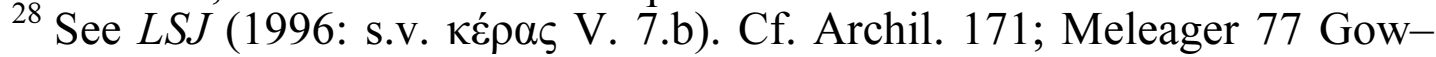

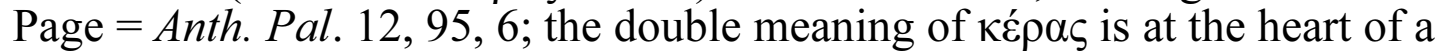
scene from Daphnis and Chloe when Daphnis tries to save one of his goats (Long. 1, 12), and also suggested by Lucian in the dialogue between Poseidon and the Nereids about Helle's falling into the sea (Luc. Dial. mar. 6, 2; see Bartley 2009: 99 ad Dial. mar. 6, 2, 10-11). 
the Egyptian magistrates of Memphis on the bare suspicion that they were lying to him about the god Apis (3, 27-28) and then wounds the bull Apis to prove to the Egyptians that he was not a $\operatorname{god}(3,29)$. He also marries his own sister, only to kill her in a fit of rage $(3,31-$ 32). One of the most memorable of scenes in this account is Prexaspes' cautious attempt at advising Cambyses to drink less (3, 34-35). To this advice Cambyses reacts with anger and sets to prove Prexaspes and other Persians wrong by demonstrating his skill in archery (the assumption being that a person driven to madness by alcohol will not be able to shoot well). Cambyses takes Prexaspes' own son as target, swearing to hit him straight in the heart:

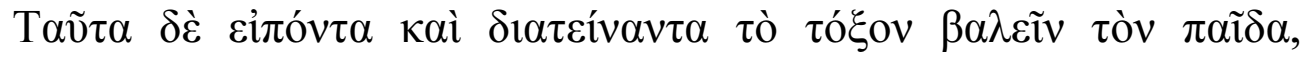

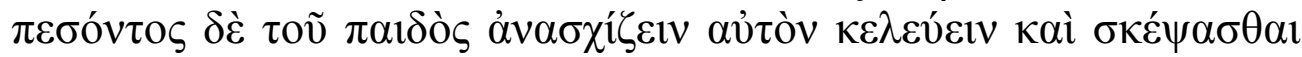

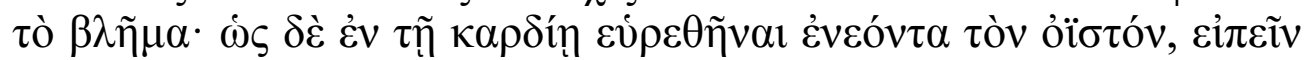

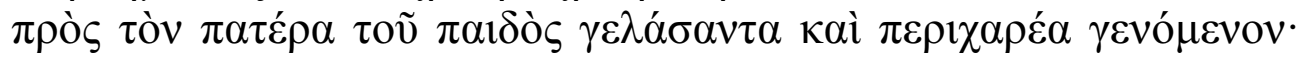

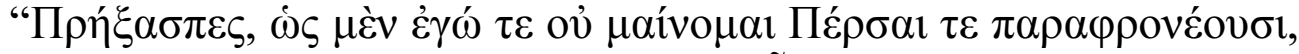

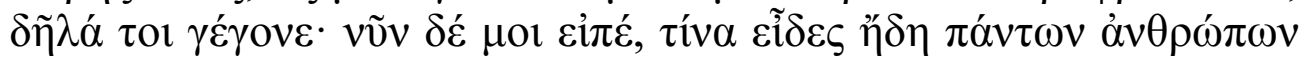

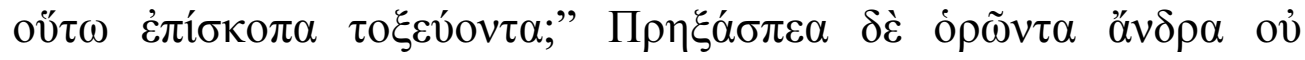

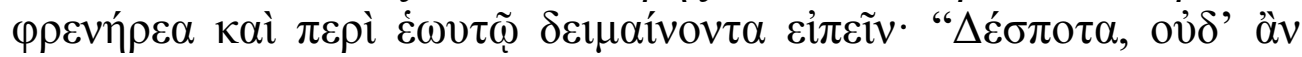
$\alpha$ $\tau$ ìv this and strung his bow, he shot the boy, and when he fell, [Cambyses] gave order to split his body open and to examine the wound. And when the arrow was found to have pierced the heart, he said, laughing and overjoyed: 'Prexaspes, it is clear to you now that I am not crazy, and that it is the Persians who are deranged: and now tell me, do you know anyone, of all people, who shoots so true to the mark?' And Prexaspes, seeing that the man was not in his rightful mind, said in fear for his own life: 'Master, I do not think that god himself could shoot so well."' (Hdt. 3, 35).

The parallelism between Hdt. 3, 35 and Anacreontea 33 is evident: Eros in his gleeful call on the host to share his joy over the excellent state of his arc displays the same lack of empathy, the same inability to see the suffering of the other party, as Cambyses did toward Prexaspes, when he called on him to admire his own skillful use of the bow as demonstrated by his killing Prexaspes' son. While the possibility that the Anacreontic poet was using an intermediary literary model based on Herodotus cannot be excluded, this is unlikely: Herodotus was popular in Hellenistic and Roman times $^{29}$, and a poet of such sophistication as the author of Anacre-

${ }^{29}$ On the reception of Herodotus in Hellenistic times, especially in the domains of paradoxography, geography and ethnography, see Priestley (2014). Tribulato's article on Herodotus' reception in the lexicographical 
ontea 33 would tend to refer to the earliest version of the story. Moreover, at least one trait in the Anacreontea 33 seems to indicate that Hdt. 3, 35 was indeed the poet's model: in his remark, Eros displaces the wound from the liver ( $\mu \varepsilon \varepsilon_{\sigma o v} \tilde{\eta} \pi \alpha \rho$, v. 28) to the heart

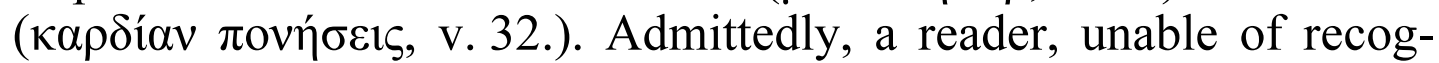
nizing the Herodotean intertext, could assume that the wound in the liver from Eros might result in life-long pain in the heart, but for a more perspicacious reader, the shift might serve as an indication that a new reference is being introduced. It is also tempting to imagine that the reference to Herodotus might have been prepared

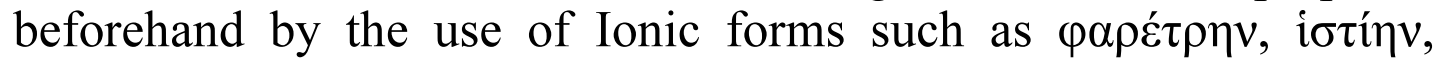

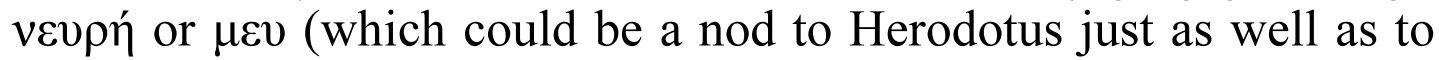

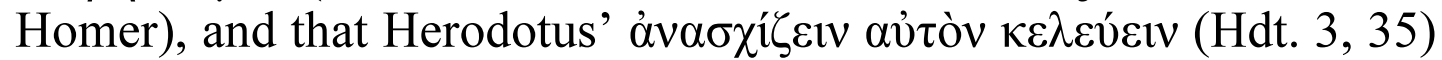
might be the reason for the Anacreontic poet's rather unexpected

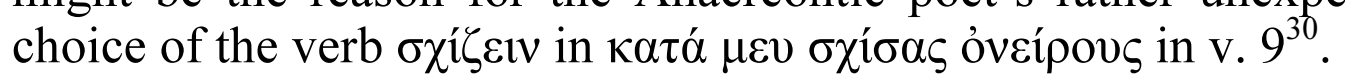

A closer look at Anacreontea 33, and especially at the references to literary models, shows that this was a poem designed for very diverse readership. A simpler reader would enjoy the story of the poet's encounter with Eros, reading it as a sort of fable on love's capricious, intractable, even cruel nature, relishing the ambiguity of

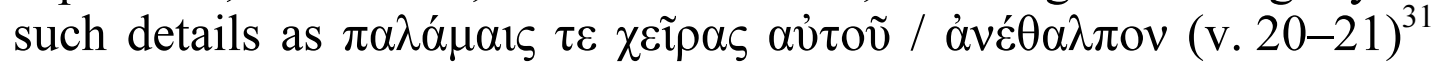

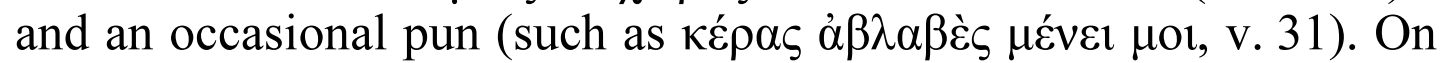
the other hand, an erudite reader, capable of recognizing the shifting intertexts and literary models, would delight in the way the Anacreontic poet plays with his expectations. In fact, no sooner does one recognize the text that the poet has just referred to that it morphs into a different reference: this play starts at the very beginning of the poem, when the Theocritean description of the night sky in vv. 1-3 gives way to a cluster of Homeric expressions in vv. 4-5, making the reader wonder whether the first three verses had not also been an allusion to Homer (Il. 18, 486-488 = Od. 5, 273-275). Closely after, verse 7 gives a first hint that a testing of the bow might be about to

tradition gives an idea as to how thoroughly he was read by literary scholars and grammarians (Tribulato 2016). Needless to say, that it is rather unexpected to find Herodotus among literary models of a poetic collection such as the Anacreontea.

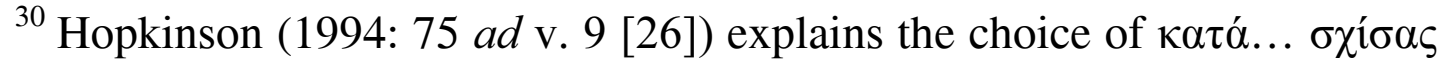
as "[the poet] applies to his dreams a word properly used of bursting open doors"; but this does not seem to be a typical usage of $\sigma \chi i \zeta \varepsilon v$.

${ }^{31}$ As Neil Hopkinson puts it in his commentary, "to warm Eros is of course a dangerous mistake" (Hopkinson 1994: 75 ad v. 21 [38]) 
take place. The middle of the poem, where the poet describes taking care of the child Eros, proceeds without recognizable literary

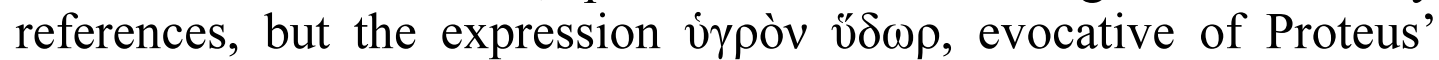
transformation into 'wet water', warns the reader to expect a new turn in the story. To be sure, this is the point when Eros will show his real colours, and simultaneously one intertextual model will morph into another: the reference to $\mu \nu \eta \sigma \tau \eta \rho o \varphi o v i ́ \alpha$ that the reader has already come to expect is transformed at the very last moment into an allusion to a very different episode involving the testing of a bow - Cambyses' killing of Prexaspes' son in Hdt. 3, 35. The purpose of this last allusion is not merely to surprise the reader by the unexpected change of intertext: it also subtly suggests the transformation of the stranded child Eros, taken in and warmed by the poet, into Eros the tyrant ${ }^{32}$.

\section{Bibliography}

Bartley, A. N. (ed., comm.) 2009: Lucian's Dialogi Marini. Newcastle upon Tyne.

Bergk, Th. (ed.) 1882: Poetae Lyrici Graeci. Vol. III: Poetas melicos continens. 4 ed. Lipsiae.

Campbell, D. A. (ed., transl.) 1988: Greek Lyric. Vol. II: Anacreon, Anacreontea, Choral Lyric from Olympus to Alcman. Cambridge Mass.; London.

Chadwick, J. 1996: Lexicographica Graeca: Contributions to the Lexicography of Ancient Greek. Oxford.

Chantraine, P. 1948: Grammaire homérique. Tome I: Phonétique et morphologie. Paris.

Cupane, C. 1973-1974: "ع̋ $\rho \varsigma \varsigma \beta \alpha \sigma i \lambda \varepsilon v ́ \varsigma$ : le figura di Eros nel romanzo bizantino d'amore", Atti dell'Accademia di Scienze, Lettere e Arti di Palermo 33, 243-297.

Delboulle, A. 1891: Anacréon et les poèmes anacréontiques : texte grec avec les traductions et imitations des poètes du XVI siècle. Havre.

Dover, K. J. (ed., comm.) 1971: Theocritus. Select Poems, Edited with an Introduction and Commentary. Basingstoke; London.

Eckstein, F. 1974: Handwerk, Teil I: Die Aussagen des homerischen Epos (Archaeologia homerica L1, ed. F. Matz, H.-G. Buchholz). Göttingen.

Fantuzzi, M. Hunter, R. 2005: Tradition and Innovation in Hellenistic Poetry. Cambridge, New York.

\footnotetext{
${ }^{32}$ The motif of slavery to love appears in Plato (Symp. 183a), and occurs regularly fairly regularly in Hellenistic poetry (e.g. Anth. Pal. 5, 100; 12, 80; 12, 81, etc.; see also Lyne 1979: 118-120). It is worth noting that in equating Eros with Cambyses, the Anacreontea 33 anticipates the motif of Eros the King that will become popular in Byzantine romance (see Cupane 1973-1974; Magdalino 1992).
} 
Giangrande, G. 1975: On the Text of the Anacreontea. Quaderni Urbinati di Cultura Classica 19, 177-210.

Gillespie, S. 2002: The Anacreontea in English: A Checklist of Translations to 1900: with a Bibliography of Secondary Sources and Some Previously Unpublished Translations. Translation and Literature 11(2), 149-173.

Gow, A. S. F. (ed., comm.) 1952: Theocritus. Vol. I-II. Cambridge.

Gow, A. S. F. Page, D. L. (ed., comm.) 1965: The Greek Anthology: Hellenistic Epigrams. Vol. I-II. Cambridge.

Gukovsky, G. A. 1927: [On the Anacreontic Ode]. In: G. A. Gukovsky. Russkaya poeziya XIII veka. Leningrad, 103-150.

Гуковский, Г. А. 1927: Об анакреонтической оде. В: Г. А. Гуковский Русская поэзия XVIII века. Л., 103-150.

Hopkinson, N. (ed., comm.) 1994: Greek Poetry of the Imperial Period: An Anthology. Cambridge.

Lambin, G. 2002: Anacréon: fragments et imitations. Rennes.

Lappo-Danilevskij, K. Yu. 2017: [Russian Anacreontic ode (Reflecting on G. A. Gukovsky's article from 1927]. In: Literaturnaya zhizn' Rossii XVIII veka. Moscow, Saint-Petersburg, 113-134.

Лаппо-Данилевский, К. Ю. 2017: Русская анакреонтическая ода (размышления в связи со статьей Г. А. Гуковского 1927 года). B: Литературная жизнь России XVIII века (XVIII век: сборник 29). М.; СПб., 113-134.

Lelli, E. 2003: Elementi di folklore nei Giambi di Callimaco. In: L. Belloni, L. de Finis, G. Moretti (eds.) L'officina ellenistica: poesia dotta e popolare in Grecia e a Roma. Trento, 475-492.

LfgrE 1955-2006: Lexikon des frühgriechischen Epos, begründet von B. Snell. Bd. I-IV. Göttingen.

LSJ 1996: A Greek - English Lexicon, compiled by H. G. Liddell, R. Scott, revised and augmented by H.S. Jones, R. McKenzie, with a revised supplement. Oxford.

Lyne, R. O. A. M. 1979: Servitium amoris. Classical Quarterly 29, 117130.

Magdalino, P. 1992: Eros the King and the King of Amours: Some Observations on Hysmine and Hysminias. Dumbarton Oaks Papers 46, 197-204.

Page, D. L. (ed.) 1962: Poetae melici Graeci. Oxford.

Priestley, J. 2009: Tmesis in Herodotus. Glotta 85, 118-178.

Priestley, J. 2014: Herodotus and Hellenistic Culture: Literary Studies in the Reception of the Histories. Oxford; New York.

Rosenmeyer, P. A. 1992: The Poetics of Imitation: Anacreon and the Anacreontic Tradition. Cambridge.

Rosenmeyer, P. A. 1999: Tracing medulla as a locus eroticus. Arethusa 32(1), 19-47.

Russo, J. Fernández-Galliano, M. Heubeck, A. (comm.) 1992: Homer's Odyssey. Vol. III: Books XVII-XXIV. Oxford.

Schwyzer, E. 1950: Griechische Grammatik auf der Grundlage von Karl Brugmanns Griechischer Grammatik. Bd. 1: Lautlehre, Wortbildung, Flexion, ${ }^{6}$ München. 
Scodel, R. 2011: Callimachus and Fable. In: B. Acosta-Hughes, L. Lehnus, S. Stephens (eds.), Brill's Companion to Callimachus. Leiden; Boston, 368-383.

Sviyasov, E. V. 1998: Antichnaya poeziya v russkikh perevodakh XVIII-XX vv. Bibliograficheskiy ukazatel' [Ancient Poetry in Russian Translations of the XVIII-XX centuries. A Bibliographical Repertory]. Saint-Petersburg.

Свиясов, Е. В. 1998: Античная поэзия в русских переводах ХVIII-ХХ. Библиографический указатель. СПб.

Sens, A. 2014: Dialect in the Anacreontea. In: M. Baumbach, N. Dümmler (eds.) Imitate Anacreon! Mimesis, Poiesis and the Poetic Inspiration in the Carmina Anacreontea. Berlin; Boston, 97-112.

Tribulato, O. 2016: Herodotus' Reception in Ancient Greek Lexicography and Grammar, from the Hellenistic to the Imperial Age. In: J. Priestley, V. Zali (eds.) Brill's Companion to the Reception of Herodotus in Antiquity and Beyond. Leiden; Boston.

West, M. L. (ed.) 1984: Carmina Anacreontea. Leipzig.

West, M. L. 1974: Studies in Greek Elegy and Iambus. Berlin; New York.

Zotou, A. (ed., comm.) 2014: Carmina Anacreontea 1-34: Ein Kommentar. Berlin; Boston. 